induced, have threshold values below which they do not operate. More importantly, multiple events will not have cumulative effects unless they are essentially simultaneouss.

Is Manson then one of a virtually simultaneous series of multiple impacts that may have occurred at the $\mathrm{K} / \mathrm{T}$ boundary? Unfortunately, this is not without its own set of problems. Crater dimensions and other attributes, such as volumes of ejected dust, that might affect the biosphere, do not scale linearly with impact energy. For example, crater dimensions scale approximately as the fourth power of the energy. The impact energy required to form Manson is of the order of $10^{21}$ joules. A rough mass-balance calculation ${ }^{4}$ for the size of projectile required to account for the siderophile anomaly at the $\mathrm{K} / \mathrm{T}$ boundary suggests that the energy release for the $\mathrm{K} / \mathrm{T}$ event was of the order to $10^{23}$ joules. That is enough to form 100 Manson-sized structures or some combination of smaller and larger-sized structures. If Manson is one of several $\mathrm{K} / \mathrm{T}$ boundary structures, where are the others? The terrestrial cratering record suggests that a Manson-sized structure is formed somewhere on the land surface of the Earth every 5 million years. It is possible that it is simply a coincidence that Manson has an age equivalent to the $\mathrm{K} / \mathrm{T}$ boundary and that the associated impact is unrelated to the $\mathrm{K} / \mathrm{T}$ extinction.

The best ages for impact events are obtained using ${ }^{39} \mathrm{Ar}-{ }^{40} \mathrm{Ar}$ dating on rocks that have been melted by the impact. These rocks have the best chance of being degassed and having their radiogenic argon clock reset. The samples analysed by Kunk et al. have not been melted, only shocked to much lower pressures. The argon spectra of these samples do not have a good plateau age but rather have a slight U-shape. When dealing with impact melt rocks, the minimum of the $U$ in this type of spectrum is generally taken to represent a maximum age for the event $t^{6}$. The fact that two samples give similar ages may mean nothing more than they happen to have undergone similar shock and post-shock thermal histories, resulting in equivalent ${ }^{40} \mathrm{Ar}$ loss and reset ages. If impact melt rocks are discovered at Manson and also give a similar age then we can be more confident that Manson has an age equivalent to the $\mathrm{K} / \mathrm{T}$ boundary.

Richard A.F. Grieve is in the Geophysics Division, Geological Survey of Canada, Ottawa, K1A OY3, Canada.

1. Garwin, L. Nature 336, 714-716 (1988)

2. Kunk, M.J., Izett, G.A., Haugerud, R.A. \& Sutter, J.F. Science 244, 1565-1568 (1989).

3. French, B.M. Science 226, 353 (1984)

4. Alvarez, L., Alvarez, W.. Asaro, F. \& Michel, H. Science 208, 1095-1108 (1980).

5. Prinn, R. G. \& Fegley, B. Jt Earth planet. Sci. Lett. 83, 1-15 (1987).

6. Bottomley, R.J. \& York, D. Lunar planet. Sci. XX, 101 (1989)

NATURE · VOL 340 10 AUGUST 1989

\title{
And now, small is plentiful
}

\author{
Evelyn B. Sherr
}

ON PAGE 467 of this issue ${ }^{1}$, Bergh et al. report the use of transmission electron microscopy to make direct counts of femtoplankton - viruses of less than $0.2 \mu \mathrm{m}$ in size ${ }^{2}$ in natural waters. They find up to $10^{8}$ viruses per $\mathrm{ml}$, which is three to seven orders of magnitude higher than previous abundance estimates based on plaque-forming units. The earlier estimates had led to the conjecture that instances of bacteriophage infection of suspended bacteria would be rare $^{3}$; now all bets are off.

During the past few decades, aquatic ecologists have been involved in elucidating the trophic roles of ever smaller life forms (somewhat in analogy to the physicists' search for ever smaller sub-atomic particles). In the 1960 s and 1970 s, nanoplanktonic algae, less than $10-20 \mu \mathrm{m}$ in size, were a major focus of investigation as the most important component of pelagic primary production ${ }^{4}$. In the 1970 s and 1980 s, picoplankton, with cells of less than $2 \mu \mathrm{m}$ in size, were found to be much more abundant and active than previous work had suggested ${ }^{5.6}$. Direct count microscopic methods revealed that the true abundance of heterotrophic bacterioplankton, $10^{5}-10^{7}$ per $\mathrm{ml}$ was much greater than previous estimates of viable bacteria based on plate counts ${ }^{7.8}$. Along with the greater densities of heterotrophic bacteria, the reports of high concentrations of picoalgae, including unicellular bluegreens $^{6,9}$ and eukaryotic algae the size of large bacteria ${ }^{10}$, were electrifying.

These discoveries have contributed to a revolution in our understanding of the functioning of pelagic food webs. The original concept of a linear food chain in the sea - phytoplankton to copepods to fish - is no longer a viable model for how pelagic ecosystems operate. In fact, we are only now beginning to grapple with the idea that in many aquatic ecosystems, including much of the world ocean, most carbon fixation is carried out by cells too small for copepods to ingest - they pass right through the copepod sieving apparatus. The significance of heterotrophic bacterioplankton has received strong support from the finding that the greatest fraction of particulate organic matter in the water column of the open ocean is in fact metabolically active bacterial cells ${ }^{11}$. It now appears that a complex network of trophic pathways among microbes, including algae, bacteria and protozoa, accounts for the bulk of the carbon and energy flows, with a small fraction of the total microbial production going to support all the other consumers, from copepods to whales ${ }^{12}$.

Against this backdrop, the focus in aquatic microbial ecology for the 1990s may well be the trophic and evolutionary implications of the high abundances of viruses in natural waters found by Bergh et al. . As they say in their report, attack by bacteriophages could explain the unaccountably high mortality rates of bacteria measured in some systems. Viral infection can also kill eukaryotic microbes ${ }^{13}$, and viruses might account for some of the 'dissolved' DNA found in seawater ${ }^{14}$.

The most fundamental implication of high viral abundance is, however, that routine bacteriophage infection of aquatic bacteria is likely to result in significant exchange of genetic material ${ }^{15}$. Natural genetic engineering experiments may have been occurring in bacterial populations for eons. If bacteriophage transduction turns out to be a common mechanism for gene transfer in aquatic ecosystems, then pelagic bacterial assemblages should be able to adapt more rapidly to new situations than has been thought. They might, for example, rapidly develop resistance to antibiotics used in aquaculture, or elaborate enzymes able to act on exotic chemicals introduced into the environment. There is also the disturbing possibility that indigenous bacteria could acquire traits from pathogenic bacteria or artificially engineered bacteria released into lakes and coastal waters ${ }^{15}$

I expect that the discovery reported by Bergh et al. will spur research, only just now beginning, into the genetic composition of bacterioplankton ${ }^{16}$, as well as promote further studies of the prevalence and activity of femtoplankton, the smallest 'living' particles in natural waters.

Evelyn B. Sherr is at the University of Georgia Marine Institute, Sapelo Island, Georgia 31327, USA.

1. Bergh, O., Borsheim, K.Y., Bratbak, G. \& Heldal, G. Nature 340, 467-468 (1989)

2. Sieburth, J.McN., Smetacek, V. \& Lenz, J. Limnol. Oceanogr. 23, 1256-1263 (1978).

3. Wiggins, B.A. \& Alexander, M. Appl. environ. Microbiol. 49, 19-23 (1985).

4. Malone, T.C. in Primary Productivity in the Sea (ed. Falkowski, P.G.) 301-320 (Plenum, New York, 1980).

5. Pomeroy, L.R. BioScience 24, 449-504 (1974).

6. Platt, T., Subba Rao, D.V. \& Irwin, B. Nature 310, 702 704 (1983).

Jannasch, H.W. \& Jones, G.E. Limnol. Oceanogr. 4 128-139 (1959).

8. Watson, S.W., Novitsky, T.J., Quinby, H.L. \& Valois, F.W. Appl. environ. Microbiol. 33, 940-946 (1977).

9. Johnson, P.W. \& Sieburth, J. McN. Limnol. Oceanogr. 24 928-935 (1979).

10. Johnson, P.W. \& Sieburth, J. McN. J. Phycol. 18, 318327 (1982).

11. Cho, B.C. \& Azam, F. Nature 332, 424-425 (1988).

12. Sherr, E.B. \& Sherr, B.F. Limnol. Oceanogr. 33, 12251227 (1988).

13. Mayer, J.A. \& Taylor, F.J.R. Nature 281, 299-301 (1979)

14. Deflaun, M.F., Paul, J.H. \& Jeffrey, W.H. Mar. Ecol. Prog. Ser. 38, 65-73 (1987).

15. Trevors, J.T., Barkay, T \& Bourquin, A.W. Can. J. Microbiol. 33, 191-198 (1987)

16. Pace, N.R.et al. in Advances in Microbial Ecology (ed. Marshall, K.C.) 1-56 (Plenum, New York, 1986). 